\section{Root-knot Nematode Resistance, Yield, and Fruit Quality of Specialty Melons Grafted onto Cucumis metulifer}

\author{
Wenjing Guan and Xin Zhao \\ Horticultural Sciences Department, University of Florida, Gainesville, FL \\ 32611
}

Donald W. Dickson and Maria L. Mendes
Entomology and Nematology Department, University of Florida, Gainesville,
FL 32611

Judy Thies

USDA, ARS, U.S. Vegetable Laboratory, 2700 Savannah Highway, Charleston, SC 29414

Additional index words. flesh firmness, Meloidogyne, organic production, root galling, soluble solids content, rootstock

Abstract. Interest in specialty melons (Cucumis melo) with distinctive fruit characteristics has grown in the United States in recent years. However, disease management remains a major challenge in specialty melon production. In this study, grafting experiments were conducted to determine the effectiveness of using Cucumis metulifer, a species known for its genetic resistance to root-knot nematodes (RKNs; Meloidogyne spp.), as a potential rootstock for managing RKNs in susceptible specialty melon cultivars. In the greenhouse experiment, honeydew melon 'Honey Yellow' was grafted onto $C$. metulifer and inoculated with $M$. incognita race 1 . The grafted plants exhibited significantly lower gall and egg mass indices and fewer eggs compared with non- and self-grafted 'Honey Yellow'. Cucumis metulifer was further tested as a rootstock in conventional and organic field trials using honeydew melon 'Honey Yellow' and galia melon 'Arava' as scions. 'Honey Yellow' and 'Arava' grafted onto $C$. metulifer exhibited significantly lower galling and reduced RKN population densities in the organic field; however, total and marketable fruit yields were not significantly different from non- and self-grafted plants. Although the improvement of RKN resistance did not translate into yield enhancements, incorporating grafted specialty melons with $C$. metulifer rootstock into double-cropping systems with $\mathrm{RKN}$-susceptible vegetables may benefit the overall crop production by reducing $R K N$ population densities in the soil. At the conventional field site, which was not infested with RKNs, 'Honey Yellow' grafted onto $C$. metulifer rootstock had a significantly lower total fruit yield than non-grafted 'Honey Yellow' plants; however, fruit yields were similar for 'Arava' grafted onto $C$. metulifer rootstock and non-grafted 'Arava' plants. Although no significant impacts on the fruit quality attributes of 'Honey Yellow' were observed, grafting onto $C$. metulifer decreased the flesh firmness of 'Arava' in both field trials and resulted in a reduction in total soluble solids content under conventional production. In summary, grafting $\mathrm{RKN}$-susceptible melons onto $C$. metulifer rootstock offers promise for growing these specialty melons; however, more studies are needed to elucidate the scion-rootstock interaction effect on fruit yield and quality.

Specialty melons generally refer to melon types other than cantaloupe, which is the most widely grown melon type in the United States. Galia, ananas, persian, honeydew, casaba, crenshaw, canary, and asian melons are among the major specialty melons in the market (Strang et al., 2007). Driven by the consumer preference for healthy and specialty produce, demand for specialty melons

Received for publication 3 Feb. 2014. Accepted for publication 14 May 2014.

This research was funded by a Southern Region SARE (Sustainable Agriculture Research and Education) Research and Education Grant (LS10-233).

${ }^{1}$ To whom reprint requests should be addressed; e-mail zxin@ufl.edu.
(Nickle, 1991; Taylor and Sasser, 1978). $M$. incognita race 1 was reported as the most common race, accounting for $60 \%$ in a worldwide collection (Taylor and Sasser, 1978).

In conventional production systems, management of RKNs in high-value horticultural crops is largely dependent on soil fumigation (Duniway, 2002). Given the increasing costs and rising environmental concerns associated with soil fumigation, alternative approaches are needed for integrated management to improve sustainable melon production (Martin, 2003). Under organic production, RKN management is more challenging because of their wide host range and the lack of highly effective management strategies. The use of soil solarization, cover crops, soil amendment, and biological control for disease and nematode management often yields only moderate results (Oka et al., 2007).

Resistant cultivars are a cornerstone of RKN management in both vegetable and agronomic crops (Williamson and Roberts, 2010). Resistances in plants are either naturally occurring or transferred to crop cultivars through breeding. Naturally occurring resistance was found in wild species of Cucumis such as $C$. metulifer and C. anguria (Fassuliotis, 1967; Thies and Levi, 2013; Wehner et al., 1991) and wild melon C. melo var. texanus (Faske, 2013), but it was absent in melon cultivars (Thomason and McKinney, 1959). Incorporating RKN resistance from C. metulifer into $C$. melo was unsuccessful, because the interspecific hybridization failed to set fruit or produce viable seeds (Deakin et al., 1971).

Vegetable grafting was proposed as an alternative approach to take advantage of RKN resistance in wild Cucumis species (Kokalis-Burelle and Rosskopf, 2011; Sigüenza et al., 2005; Thies et al., 2013). Because grafted plants combine desirable characteristics from both rootstock and scion plants, RKNs can be managed by grafting melon cultivars with desirable horticultural traits onto rootstocks containing RKN resistance. Grafting has been shown to be an effective tool for combating several soilborne diseases in cucurbit production worldwide (Davis et al., 2008; Guan et al., 2012). Unfortunately, all currently available commercial melon rootstocks are susceptible to many of the RKN species, thereby making development of resistant rootstocks a pressing need in melon production.

Cucumis metulifer can be used as a rootstock for grafting cantaloupe melons (Kokalis-Burelle and Rosskopf, 2011; Lee and Oda, 2003; Sigüenza et al., 2005; Thies et al., 2013). However, information is limited regarding its grafting compatibility with other melon types and the rootstock effects on yield and fruit quality of the grafted plants. Understanding the influence of $C$. metulifer on the fruit quality is particularly important, because specialty melons are typically marketed for their outstanding taste and unique flavor.

In this study, C. metulifer was used as a rootstock for grafting honeydew and galia melons. We conducted a RKN inoculation study in the greenhouse and two field trials 
under conventional and organic production systems. The objectives were to determine the effects of $C$. metulifer on RKN management, yield performance, and fruit quality of grafted plants.

\section{Materials and Methods}

Plant materials. Two specialty melons, honeydew melon 'Honey Yellow' (C. melo var. inodorus) and galia melon 'Arava' (C. melo var. reticulatus) (Johnny’s Selected Seeds, Winslow, ME), were evaluated as scions grafted onto $C$. metulifer rootstock. A $C$. metulifer line (USVL-M0046) was selected for RKN resistance and grafting compatibility with cantaloupe melons from PI 526242 (U.S. PI C. metulifer Collection) (J.A. Thies, U.S. Vegetable Laboratory, USDA, ARS, Charleston, SC, unpublished data). USVL-M0046 was self-pollinated to produce S2 and S3 seeds (provided by USDA, ARS, Charleston, SC), which were used as the $C$. metulifer rootstocks in the present greenhouse and field studies, respectively.

Greenhouse RKN study. The greenhouse RKN inoculation study was conducted during Fall 2011. Honeydew melon 'Honey Yellow' scion was grafted onto $C$. metulifer rootstock. Non-grafted and self-grafted 'Honey Yellow' as well as non-grafted $C$. metulifer were included as controls.

The RKN ( $M$. incognita race 1) inoculum used in this experiment was obtained from an isolate that originated from tobacco grown in north Florida and was maintained and multiplied on tomato 'Rutgers' (Solanum lycopersicum) in the greenhouse. The RKN species and race were identified by using isozyme electrophoresis and differential host tests (Taylor and Sasser, 1978).

Rootstock and scion seeds were planted on 8 and 10 July 2011, respectively. Seeds were sown into 128-cell Styrofoam flats (Sun City, FL). The cells were filled with conventional potting soil with a mixture of vermiculite, peatmoss, perlite, and starter nutrient (Metro-Mix 200; Sun Gro Horticulture, Bellevue, WA). Seedlings were grafted on 22 July using the one-cotyledon method (Davis et al., 2008). After grafting, plants were immediately placed into a light-blocking healing chamber in the greenhouse where temperature was maintained at $28 \pm 3{ }^{\circ} \mathrm{C}$ and relative humidity was $90 \%$ to $95 \%$. After 3 d, humidity in the healing chamber was gradually reduced, and grafted plants were exposed to light. At $7 \mathrm{~d}$ after grafting, plants were removed from the healing chamber and grown in the greenhouse for another $7 \mathrm{~d}$. Completely healed grafted plants and non-grafted plants were then transplanted individually into 15 -cm-diameter clay pots containing pasteurized soil (89\% sand, 3\% silt, $5 \%$ clay; $\mathrm{pH} 6.1,1.1 \%$ organic matter) and a slow-release fertilizer $18 \mathrm{~N}-2.6 \mathrm{P}-9.9 \mathrm{~K}$ (Osmocote; The Scotts Company, Marysville, $\mathrm{OH})$ added at $6 \mathrm{~g}$ nitrogen $(\mathrm{N}) /$ pot. Seven $\mathrm{d}$ after transplanting, the plants were then moved to a shadehouse and inoculated with 5000 eggs of $M$. incognita race 1 . Ten milliliters
(500 eggs $/ \mathrm{mL}$ ) of nematode inoculum were evenly dispensed into three 6-cm-deep holes around the plants and topped with moist soil to protect eggs from desiccation. Plants were arranged in a completely randomized design with five plants that served as five replications in each treatment.

Plants were grown in the shadehouse for 8 weeks with air temperatures ranging from 24 to $39^{\circ} \mathrm{C}$. Fertilized female flowers were removed to prevent fruit formation. The experiment was ended on 15 Oct. Roots were washed gently and allowed to air-dry. Then the roots were stained with $10 \%$ (v:v) solution of red food coloring (Thies et al., 2002) to aid with an estimation of the amount of galling and egg masses based on a 0 to 5 scale (Taylor and Sasser, 1978). The number of eggs per root system was counted after their extraction using a $0.25 \%$ sodium hypochlorite solution and blender technique (Hussey and Barker, 1973). Eggs were quantified with a nematode chamber counting slide under a 40× magnification microscope. Nematode reproduction factor (Rf) was calculated as the ratio of final eggs recovered to the initial inoculum number.

Field study. Two field experiments were conducted during Spring 2012, one in a certified organic field (Quality Certification Services, Gainesville, FL) and another in a fumigated conventional field. Honeydew melon 'Honey Yellow' and galia melon 'Arava' scions were grafted onto C. metulifer rootstock for the field trials. Untreated 'Honey Yellow' seeds were used for both trials, and untreated and organic 'Arava' seeds were used for the conventional and organic trials, respectively. Seeds of C. metulifer and melon cultivars were sown on 20 and 22 Feb., respectively. A peat-based medium (Natural \& Organic 10; Fafard, Agawam, MA) was used for organic transplants. Organic fertilizer $2 \mathrm{~N}-1.3 \mathrm{P}-0.8 \mathrm{~K}$ (organic fish and seaweed; Neptune's Harvest, Gloucester, MA) was applied three times a week after seed germination at a concentration of $90 \mathrm{mg} / \mathrm{L}$ (based on $\mathrm{N}$ ) for organic transplants. Conventional potting soil Metro-Mix 200 was used for conventional seedling production. Two weeks after seed germination, conventional plants were fertilized twice a week with $20 \mathrm{~N}-8.7 \mathrm{P}-16.6 \mathrm{~K}$ (Peters Professional; United Industries, St. Louis, MO) at a concentration of $120 \mathrm{mg} / \mathrm{L}$ (based on N). Plants were grafted on 8 Mar. as previously described for the greenhouse study.

The field experiments were conducted at the University of Florida Plant Science Research and Education Unit, Citra, FL. The organic site was naturally infested with RKNs. The RKN-susceptible okra 'Clemson Spineless' (Abelmoschus esculentus) was grown in the plots from Aug. to Dec. 2011 to increase the RKN population density. The beds in both organic and conventional fields were $76 \mathrm{~cm}$ wide $\times 23 \mathrm{~cm}$ high and row centers were spaced at $1.8 \mathrm{~m}$. Beds in the conventionally managed field were prepared and fumigated with methyl bromide-chloropicrin (50:50, by weight) mixture at a dosage of $454 \mathrm{~kg} / \mathrm{ha}$ 3 weeks before transplanting. Fumigant was applied $25 \mathrm{~cm}$ deep in the bed, and the beds were immediately covered with low-density black polyethylene film (Intergro, Safety Harbor, FL). A double-wall single drip tube (Chapin, Watertown, NY) with emitters spaced $30.5 \mathrm{~cm}$ apart and a flow rate of 1.9 $\mathrm{L} / \mathrm{min} / 30.5 \mathrm{~m}$ was placed under the polyethylene mulch near the row center. Drip irrigation was applied twice or three times daily based on plant growth and need throughout the season. In both fields, the treatments were: non-grafted 'Honey Yellow' and 'Arava' and 'Honey Yellow' and 'Arava' scions grafted onto C. metulifer rootstock. Self-grafted 'Honey Yellow' and 'Arava' were also planted as controls in the organic field. The experimental design for both field trials was a randomized complete block design with five replications and eight plants per treatment per replication.

Melon plants were transplanted into the organic and conventional fields on 29 Mar. 2012. Plant in-row spacing was $0.9 \mathrm{~m}$. In the organic field, $10 \mathrm{~N}-0.9 \mathrm{P}-6.6 \mathrm{~K}$ fertilizer (All Season Fertilizer; Nature Safe, Cold Spring, $\mathrm{KY}$ ) was applied preplant at $224 \mathrm{~kg} \mathrm{~N} / \mathrm{ha}$ and supplemented by weekly injection of liquid fertilizer 2N-1.3P-0.8K (Neptune's Harvest; Gloucester, MA) at a rate of $2.3 \mathrm{~kg} \mathrm{~N} / \mathrm{ha}$. In the conventional field, $10 \mathrm{~N}-4.4 \mathrm{P}-8.3 \mathrm{~K}$ fertilizer (Premium Vegetable Grower Fertilizer; Southern States, Lebanon, KY) was applied preplant at $84 \mathrm{~kg} \mathrm{~N} / \mathrm{ha}$, and $6 \mathrm{~N}-0 \mathrm{P}-6.6 \mathrm{~K}$ fertilizer (Dyna Flo; Chemical Dynamics, Plant City, FL) was injected weekly at a rate of $14.0 \mathrm{~kg} \mathrm{~N} / \mathrm{ha}$. Cucurbit disease and insect controls for both conventional and organic crops followed the University of Florida Institute of Food and Agricultural Sciences Extension recommendations (Olson et al., 2010). All pesticides used in the organic field were approved by the Organic Materials Review Institute. Plots were hand-weeded in the organic field. In the conventional field, glyphosate (Roundup; Monsanto Company, St. Louis, MO) and halosulfuron-methyl (Sandea; Gowan Company, Yuma, AZ) were applied preplant for weed control.

Melons were harvested seven times from 21 May to 10 June and nine times from 21 May to 22 June in the organic and conventional fields, respectively. 'Arava' was harvested at the full-slip stage, and 'Honey Yellow' was harvested based on the external fruit color. At the beginning of the first harvest, soluble solids contents (SSC) of 10 'Honey Yellow' melons with slight variations in fruit color were tested. Among them, the highest SSC was $16 \%$, and the color that corresponded to the highest SSC was then used as the harvest index for 'Honey Yellow' (Guan et al., 2013). Immature melons were also harvested at the final harvest and separated from ripened fruit. Fruit were weighed individually. Small fruit (weighing less than $0.45 \mathrm{~kg}$ ), immature, and misshapen fruit, and fruit with cracking and sunburn as well as defective fruit with insect or disease 
damage were categorized as unmarketable fruit.

After the final harvest of the organic field, the root systems of eight plants were dug and rated for RKN galling on a 0 to 10 scale (Zeck, 1971). Soil cores (1.75-cm diameter $\times$ $20-\mathrm{cm}$ depth) were collected in the root zone of six plants in the center of each plot. Each soil sample was thoroughly mixed and second-stage juveniles (J2) were extracted from $100 \mathrm{~cm}^{3}$ soil of each sample using a centrifugal-flotation method (Jenkins, 1964). In addition, two RKN females were excised from each of five randomly selected plants from the organic field and were identified to species using specific polymerase chain reaction primers (Dong et al., 2001). In the conventional field plot, 20 randomly selected plants for each melon cultivar were dug and rated for galling.

Fruit harvested on 6 June and 11 June in the organic and conventional field, respectively, were used for quality assessment. Three representative marketable fruit from each treatment for each replication were randomly selected. Flesh firmness and SSC were measured twice for each fruit at the middle mesocarp tissue. A penetrometer (Fruit Tester; Wagner Instruments, Greenwich, CT) with an $8-\mathrm{mm}$ plunger was used to measure flesh firmness. SSC was determined using a refractometer (AR200; Reichert Technologies, Depew, NY).

Statistical analyses. Analysis of variance was performed using the Proc Glimmix program of SAS statistical software package for Windows (Version 9.2C for Windows; SAS Institute, Cary, NC). Tukey's honestly significant difference test $(\alpha=$ 0.05 ) was conducted for multiple comparisons of different measurements among treatments.

\section{Results and Discussion}

Greenhouse RKN study. The Rf values were used to determine RKN resistance. Plants with $\mathrm{Rf}$ greater than 1 were considered susceptible (Sasser et al., 1984). C. metulifer exhibited resistance $(\mathrm{Rf}=0.48)$ and 'Honey Yellow' was susceptible $(\mathrm{Rf}=22.0)$ to M. incognita race 1 (Table 1).

Most of the previous studies on RKN resistance of $C$. metulifer were conducted with $M$. incognita race 3 or an unspecified race of M. incognita (Dalmasso et al., 1981; Fassuliotis, 1967; Nugent and Dukes, 1997; Sigüenza et al., 2005; Thies and Levi, 2013; Walters et al., 2006). In the present inoculation experiment, $M$. incognita race 1 was used as the inoculum to assess the RKN resistance of C. metulifer. We recovered $2395 \mathrm{RKN}$ eggs per plant from an initial inoculum level of 5000 eggs per plant, which indicated that $C$. metulifer has resistance to $M$. incognita race 1. This finding was similar to that reported by Nugent and Dukes (1997) in which 2900 eggs per plant were extracted from roots of $C$. metulifer plants that had been inoculated with 5000 eggs per plant of $M$. incognita race 3 . In addition to $M$. incognita,
C. metulifer has also been reported resistant to $M$. arenaria and M. javanica (Walters et al., 1993). Fassuliotis (1970) found no hypersensitive reaction to infection by $M$. incognita, but the development of $\mathrm{J} 2$ to adult was delayed in C. metulifer.

'Honey Yellow' grafted onto C. metulifer showed significantly lower root gall index (GI), egg mass index (EMI), and Rf than non-grafted and self-grafted 'Honey Yellow', indicating grafting RKN-susceptible melon onto $C$. metulifer was effective in reducing RKN reproduction. No significant differences in EMI and Rf were observed between non-grafted C. metulifer and 'Honey Yellow' grafted onto $C$. metulifer.

Field study of RKN management. Recorded $8 \mathrm{~d}$ after grafting, the survival rates of 'Honey Yellow' and 'Arava' grafted onto C. metulifer were both above $80 \%$, which were similar to that of self-grafted melons (data not shown). Graft incompatibility was not observed between the two specialty melon cultivars and the $C$. metulifer rootstock.

No root galling was observed on plants in the conventional field, indicating RKN infestation was reduced to an undetectable level in the fumigated soil. The RKN species in the naturally infested organic field was identified as M. javanica. Both non-grafted and self-grafted 'Honey Yellow' and 'Arava' plants exhibited severe galling (GI greater than 4) (Table 2). Root galling was significantly reduced on 'Honey Yellow' and 'Arava' grafted onto $C$. metulifer (GI less than 1). Grafting with $C$. metulifer rootstock also reduced $\mathrm{J} 2$ numbers in the soil compared with non-grafted melon plants, suggesting that grafting RKN-susceptible specialty melon cultivars onto $C$. metulifer could be an effective approach in reducing RKN damage and decreasing nematode population densities in the soil.

Preplant RKN density can have an important impact on plant growth and yield (Barker and Olthof, 1976). Crop rotation is commonly suggested as a management tactic for reducing RKN population densities in the soil. Thies et al. (2003) demonstrated that double-cropping cucumber and squash after RKN-resistant bell pepper increased the yields of cucumber and squash. Yield improvement was also observed on muskmelons that were double-cropped after RKN-resistant tomato (Hanna, 2000). RKN population densities for 'Honey Yellow' and 'Arava' scions grafted onto $C$. metulifer were $\approx 99.7 \%$ and $97.6 \%$ lower, respectively, than non-grafted plants of the same melon cultivars in the organic field. Thus, incorporating melons grafted onto $C$. metulifer into a double-cropping system with RKN-susceptible vegetables may be an effective approach to improve overall crop yields.

Fruit yields in the organic and conventional field experiments. In the organic field experiment, despite the improved RKN management, no significant differences in total and marketable yields were observed when comparing 'Honey Yellow' and 'Arava' grafted onto C. metulifer with non-grafted and self-grafted melon plants (Table 3). Similar results were also reported on C. metulifer grafted muskmelons that exhibited resistance to fusarium wilt but did not show yield improvement

Table 1. Root gall index (GI), egg mass index (EMI), egg recovery, and reproduction factor (Rf) of grafted and non-grafted honeydew melon 'Honey Yellow' in the greenhouse study (2011).

\begin{tabular}{lcrrr}
\hline & & \multicolumn{3}{c}{ Egg } \\
Treatment $^{\mathrm{z}}$ & $\mathrm{GI}^{\mathrm{y}}$ & EMI & recovery $^{\mathrm{x}}$ & \multicolumn{1}{c}{ Rf $^{\mathrm{v}}$} \\
\hline NGHY & $5.0 \mathrm{a}^{\mathrm{v}}$ & $5.0 \mathrm{a}$ & $110,027 \mathrm{a}$ & $22.0 \mathrm{a}$ \\
$\mathrm{NGCm}$ & $0.8 \mathrm{c}$ & $0.4 \mathrm{~b}$ & $2,395 \mathrm{~b}$ & $0.48 \mathrm{~b}$ \\
$\mathrm{HY} / \mathrm{Cm}$ & $1.6 \mathrm{~b}$ & $0.4 \mathrm{~b}$ & $3,339 \mathrm{~b}$ & $0.68 \mathrm{~b}$ \\
$\mathrm{HY} / \mathrm{HY}$ & $5.0 \mathrm{a}$ & $4.6 \mathrm{a}$ & $141,500 \mathrm{a}$ & $28.3 \mathrm{a}$ \\
\hline
\end{tabular}

${ }^{\text {z } N G H Y ~=~ n o n-g r a f t e d ~ ' H o n e y ~ Y e l l o w ' ; ~ N G C m ~=~}$ non-grafted C. metulifer; HY/Cm = 'Honey Yellow' grafted onto $C$. metulifer; $\mathrm{HY} / \mathrm{HY}=$ self-grafted 'Honey Yellow'. Plants were inoculated with 5000 eggs of $M$. incognita race 1 .

${ }^{y}$ GI and EMI were rated on a 0 to 5 scale: $0=$ no galls or egg masses; 1 = one to two galls or egg masses; $2=$ three to 10 galls or egg masses; $3=11$ to 30 galls or egg masses; $4=31$ to 100 galls or egg masses; $5=$ more than 100 galls or egg masses (Taylor and Sasser, 1978).

${ }^{\mathrm{x}}$ Egg recovery $=$ number of extracted root-knot nematode eggs from the entire root system of each plant.

${ }^{\mathrm{w}} \mathrm{Rf}=$ egg recovery/initial inoculum.

vMeans within a column followed by the same letter were not significantly different according to Tukey's honestly significant difference test at $P \leq$ 0.05 .

Table 2. Root gall index (GI) and numbers of Meloidogyne javanica second-stage juveniles (J2) in soil of grafted and non-grafted honeydew melon 'Honey Yellow' and galia melon 'Arava' in the organic field study (2012).

\begin{tabular}{|c|c|c|}
\hline Treatment $^{\mathrm{z}}$ & $\mathrm{GI}^{\mathrm{y}}$ & $\begin{array}{l}\text { Meloidogyne density } \\
\text { (J2/100 } \mathrm{cm}^{3} \text { of soil) }\end{array}$ \\
\hline \multicolumn{3}{|c|}{ Honey Yellow } \\
\hline NGHY & $7.14 \mathrm{a}^{\mathrm{x}}$ & $378.2 \mathrm{a}$ \\
\hline $\mathrm{HY} / \mathrm{HY}$ & $6.70 \mathrm{a}$ & $515.6 \mathrm{a}$ \\
\hline $\mathrm{HY} / \mathrm{Cm}$ & $0.08 \mathrm{~b}$ & $1.2 \mathrm{~b}$ \\
\hline \multicolumn{3}{|c|}{ Arava } \\
\hline NGAr & $5.20 \mathrm{a}$ & $200.2 \mathrm{a}$ \\
\hline $\mathrm{Ar} / \mathrm{Ar}$ & $4.45 \mathrm{a}$ & $140.2 \mathrm{ab}$ \\
\hline $\mathrm{Ar} / \mathrm{Cm}$ & $0.15 \mathrm{~b}$ & $4.8 \mathrm{~b}$ \\
\hline
\end{tabular}

${ }^{\mathrm{z}} \mathrm{NGHY}$ and NGAr $=$ non-grafted 'Honey Yellow' and 'Arava', respectively; $\mathrm{HY} / \mathrm{HY}$ and $\mathrm{Ar} / \mathrm{Ar}=$ selfgrafted 'Honey Yellow' and 'Arava', respectively; $\mathrm{HY} / \mathrm{Cm}$ and $\mathrm{Ar} / \mathrm{Cm}=$ 'Honey Yellow' and 'Arava' grafted onto $C$. metulifer, respectively.

${ }^{\mathrm{y}} \mathrm{GI}$ was rated on a 0 to 10 scale: $0=$ no gall; $1=$ very few small galls; $2=$ small galls, more numerous and easy to detect; $3=$ numerous small galls, some may grow together; $4=$ numerous small galls, some big galls are present, but roots are still functioning; $5=25 \%$ of the root system is out of function as a result of severe galling; $6=50 \%$ of the root system is out of function as a result of severe galling; $7=75 \%$ of the root system is heavily galled and lost for production; $8=$ no healthy roots are left, the nourishment of the plant is interrupted, but the plant is still green; $9=$ the completely galled root system is rotting, the plant is dying; $10=$ plant and roots are dead (Zeck, 1971).

${ }^{\mathrm{x}}$ Means within a column followed by the same letter were not significantly different according to Tukey's honestly significant difference test at $P \leq$ 0.05 . 
as opposed to the non-grafted muskmelons (Trionfetti Nisini et al., 2002).

Yield improvement by grafting with disease-resistant rootstocks was more pronounced when disease pressure was at a relatively high level. According to Barrett et al. (2012), tomato grafted with RKN-resistant rootstock 'Multifort' had significantly higher yield when almost the entire roots of the non-grafted plants were severely damaged by RKNs (GI greater than 8). However, yield improvement was not observed when GI of non-grafted plants was between 6 and 7 . Using the same 0 to 10 GI scale (Zeck, 1971) in the present experiment, the average GI of non-grafted and self-grafted 'Honey Yellow' and 'Arava' were 6.92 and 4.82, respectively. This was in the lower range of RKN damage compared with what was previously reported (Barrett et al., 2012).

In the conventional field, no significant differences in total and marketable yields were observed between non-grafted 'Arava' and 'Arava' grafted onto C. metulifer rootstock. However, total yield of 'Honey Yellow' grafted onto $C$. metulifer was significantly lower than that of non-grafted 'Honey Yellow' in the conventional field
(Table 3). The smaller stem diameter below the graft union was observed in contrast to that above the graft union (data not shown). The growth vigor of $C$. metulifer as a potential rootstock deserves more investigations with respect to its impact on growth and development of the grafted melon plants.

Within each melon weight class, no significant differences were observed for numbers of marketable fruit among treatments. There was no indication that grafting 'Honey Yellow' and 'Arava' scions onto C. metulifer rootstock affected fruit size and uniformity (Table 4). Although some studies showed that grafting melons onto Cucurbita interspecific hybrid rootstock increased single fruit weight (Crinò et al., 2007), it may not be the case for melons grafted onto $C$. metulifer rootstock.

Fruit quality. Grafting 'Honey Yellow' melons onto $C$. metulifer did not affect the fruit flesh firmness and SSC in either the conventional or organic field trials. In contrast, fruit quality changes were observed when 'Arava' scions were grafted onto C. metulifer (Table 5). In both organic and conventional field experiments, fruit

Table 3. Total and marketable fruit yields of grafted and non-grafted honeydew melon 'Honey Yellow' and galia melon 'Arava' in the organic and conventional field studies (2012).

\begin{tabular}{|c|c|c|c|c|}
\hline \multirow[b]{3}{*}{ Treatment $^{2}$} & \multicolumn{2}{|c|}{ Organic } & \multicolumn{2}{|c|}{ Conventional } \\
\hline & Total yield & Marketable yield & Total yield & Marketable yield \\
\hline & \multicolumn{2}{|c|}{ (kg/plant) } & \multicolumn{2}{|c|}{ (kg/plant) } \\
\hline & & Honey Yellow & & \\
\hline NGHY & $4.93 \mathrm{a}^{\mathrm{x}}$ & $3.85 \mathrm{a}$ & $10.20 \mathrm{a}$ & $9.06 \mathrm{a}$ \\
\hline $\mathrm{HY} / \mathrm{Cm}$ & $3.81 \mathrm{a}$ & $3.26 \mathrm{a}$ & $8.53 \mathrm{~b}$ & $7.44 \mathrm{a}$ \\
\hline $\mathrm{HY} / \mathrm{HY}^{\mathrm{y}}$ & $4.30 \mathrm{a}$ & $3.58 \mathrm{a}$ & & \\
\hline \multicolumn{5}{|c|}{ Arava } \\
\hline NGAr & $5.85 \mathrm{a}$ & $4.21 \mathrm{a}$ & $10.06 \mathrm{a}$ & $9.59 \mathrm{a}$ \\
\hline $\mathrm{Ar} / \mathrm{Cm}$ & $5.20 \mathrm{a}$ & $2.95 \mathrm{a}$ & $9.62 \mathrm{a}$ & $8.54 \mathrm{a}$ \\
\hline $\mathrm{Ar} / \mathrm{Ar}^{\mathrm{y}}$ & $5.68 \mathrm{a}$ & $3.60 \mathrm{a}$ & & \\
\hline
\end{tabular}

${ }^{2} \mathrm{NGHY}$ and $\mathrm{NGAr}=$ non-grafted 'Honey Yellow' and 'Arava', respectively; $\mathrm{HY} / \mathrm{HY}$ and $\mathrm{Ar} / \mathrm{Ar}=$ selfgrafted 'Honey Yellow' and 'Arava', respectively; $\mathrm{HY} / \mathrm{Cm}$ and $\mathrm{Ar} / \mathrm{Cm}=$ 'Honey Yellow' and 'Arava' grafted onto C. metulifer, respectively.

'Self-grafted 'Honey Yellow' and 'Arava' were only evaluated in the organic field study.

${ }^{x}$ Means within a column followed by the same letter were not significantly different according to Tukey's honestly significant difference test at $P \leq 0.05$. harvested from 'Arava' scion grafted onto C. metulifer rootstock had significantly lower flesh firmness than non-grafted 'Arava'; and in the conventional field trial, SSC was lower for fruit harvested from 'Arava' grafted onto C. metulifer than for fruit from non-grafted 'Arava' plants.

Although melon fruit quality is generally considered part of the inherent scion characteristics, certain scion and rootstock combinations have been reported to affect melon fruit quality attributes such as appearance, flavor, texture, and nutrient content (Rouphael et al., 2010). In general, under disease or stress conditions, the grafted cucurbit plants did not deteriorate fruit quality when appropriate rootstocks were used (Huang et al., 2009; Miguel et al., 2004). The improved water and nutrient uptake by the vigorous root systems of grafted plants may lead to increased scion photosynthesis (Xu et al., 2006), which in turn may show a positive effect on fruit development. However, grafting may disturb endogenous hormone balance within plants (Lopez-Galarza et al., 2004). As a result, fruit quality may be adversely affected. In the present study, whether endogenous plant hormones contribute to the reduced fruit quality of grafted 'Arava' is unclear. Further studies are needed to explore the potential mechanisms of rootstock impact on melon quality.

\section{Conclusions}

Specialty melons grafted onto C. metulifer exhibited less root galling and lower RKN population densities in the rhizosphere than those for non-grafted and self-grafted melons. Although yield was not improved by grafting, incorporating specialty melons grafted onto C. metulifer into a double-cropping system with RKN-susceptible vegetables may be an alternative approach to manage Meloidogyne spp. and enhance production of high-value vegetables in RKN-infested fields. Future breeding efforts may be directed to develop more vigorous $C$. metulifer rootstocks with greater potential for yield enhancement in grafted melon production. Fruit quality

Table 4. Marketable fruit number per plant in different fruit size categories of grafted and non-grafted honeydew melon 'Honey Yellow' and galia melon 'Arava' in the organic and conventional field studies (2012).

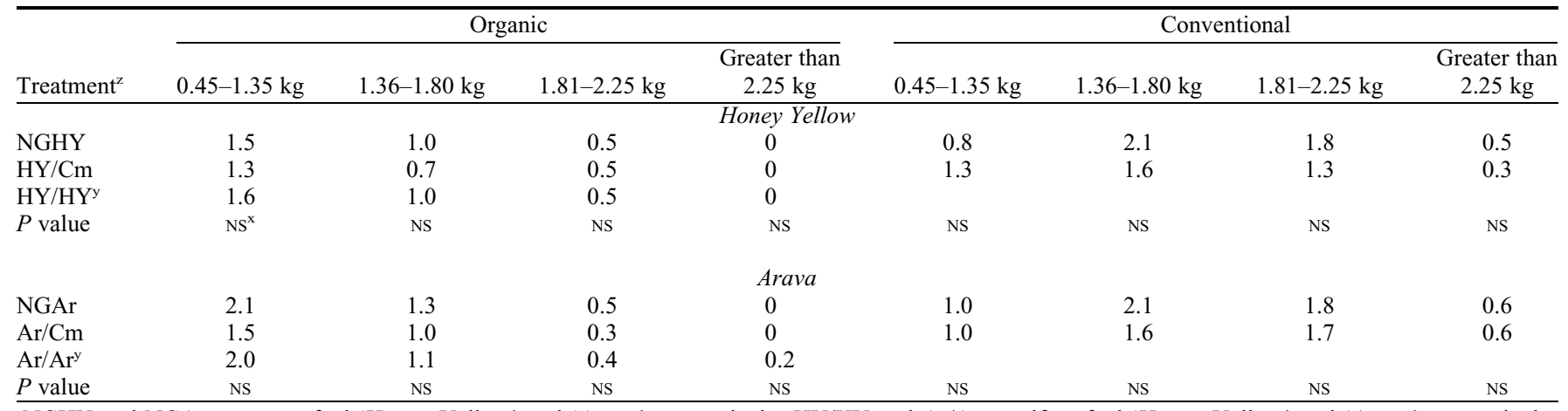

${ }^{2} \mathrm{NGHY}$ and NGAr = non-grafted 'Honey Yellow' and 'Arava', respectively; HY/HY and Ar/Ar = self-grafted 'Honey Yellow' and 'Arava', respectively;

$\mathrm{HY} / \mathrm{Cm}$ and $\mathrm{Ar} / \mathrm{Cm}=$ 'Honey Yellow' and 'Arava' grafted onto C. metulifer, respectively.

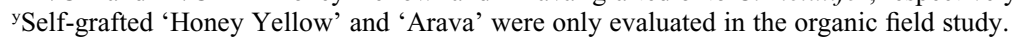

${ }^{\mathrm{N}} \mathrm{NS}=$ nonsignificant, i.e., $P>0.05$. 
Table 5. Flesh firmness and soluble solids content (SSC) of grafted and non-grafted honeydew melon 'Honey Yellow' and galia melon 'Arava' in the organic and conventional field studies (2012).

\begin{tabular}{|c|c|c|c|c|}
\hline \multirow[b]{2}{*}{ Treatment ${ }^{2}$} & \multicolumn{2}{|c|}{ Organic } & \multicolumn{2}{|c|}{ Conventional } \\
\hline & $\overline{\text { Flesh firmness (kgf) }}$ & $\overline{S S C}(\%)$ & Flesh firmness (kgf) & $\overline{S S C}(\%)$ \\
\hline & & Honey Yellow & & \\
\hline NGHY & $2.97 \mathrm{a}^{\mathrm{x}}$ & $13.56 \mathrm{a}$ & $2.59 \mathrm{a}$ & $12.88 \mathrm{a}$ \\
\hline $\mathrm{HY} / \mathrm{Cm}$ & $2.91 \mathrm{a}$ & $14.50 \mathrm{a}$ & $2.58 \mathrm{a}$ & $13.22 \mathrm{a}$ \\
\hline $\mathrm{HY} / \mathrm{HY}^{\mathrm{y}}$ & $3.11 \mathrm{a}$ & $13.69 \mathrm{a}$ & & \\
\hline & & Arava & & \\
\hline NGAr & $1.25 \mathrm{a}$ & $7.67 \mathrm{a}$ & $1.52 \mathrm{a}$ & $10.91 \mathrm{a}$ \\
\hline $\mathrm{Ar} / \mathrm{Cm}$ & $0.87 \mathrm{~b}$ & $8.23 \mathrm{a}$ & $1.21 \mathrm{~b}$ & $9.51 \mathrm{~b}$ \\
\hline $\mathrm{Ar} / \mathrm{Ar}^{\mathrm{y}}$ & $1.12 \mathrm{ab}$ & $8.71 \mathrm{a}$ & & \\
\hline
\end{tabular}

${ }^{\mathrm{z}} \mathrm{NGHY}$ and NGAr = non-grafted 'Honey Yellow' and 'Arava', respectively; $\mathrm{HY} / \mathrm{HY}$ and $\mathrm{Ar} / \mathrm{Ar}=$ selfgrafted 'Honey Yellow' and 'Arava', respectively; $\mathrm{HY} / \mathrm{Cm}$ and $\mathrm{Ar} / \mathrm{Cm}=$ 'Honey Yellow' and 'Arava' grafted onto $C$. metulifer, respectively.

'Self-grafted 'Honey Yellow' and 'Arava' were only evaluated in the organic field study.

${ }^{x}$ Means within a column followed by the same letter were not significantly different according to Tukey's honestly significant difference test at $P \leq 0.05$.

differed for galia melon 'Arava', but not for honeydew melon 'Honey Yellow', when scions were grafted onto C. metulifer rootstocks compared with non-grafted or self-grafted melons. Further studies examining specialty melon scion and $C$. metulifer rootstock interaction effects on fruit development and quality may aid in improvement of grafted specialty melon production.

\section{Literature Cited}

Barker, K.R. and T.H.A. Olthof. 1976. Relationships between nematode population densities and crop responses. Annu. Rev. Phytopathol. 14:327-353.

Barrett, C.E., X. Zhao, and R. McSorley. 2012. Grafting for root-knot nematode control and yield improvement in organic heirloom tomato production. HortScience 47:614-620.

Brito, J., T.O. Powers, P.G. Mullin, R.N. Inserra, and D.W. Dickson. 2004. Morphological and molecular characterization of Meloidogyne mayaguensis isolates from Florida. J. Nematol. 36:232-240.

Crinò, P., C.L. Bianco, Y. Rouphael, G. Colla, F. Saccardo, and A. Paratore. 2007. Evaluation of rootstock resistance to fusarium wilt and gummy stem blight and effect on yield and quality of grafted 'Inodorus' melon. HortScience 42:521-525.

Dalmasso, A., R.D. de Vaulx, and M. Pitrat. 1981. Responses of some Cucurbita and Cucumis accessions to three Meloidogyne species. Cucurbit Genet. Coop. Rpt. 4:5355.

Davis, A.R., P. Perkins-Veazie, Y. Sakata, S. LópezGalarza, J.V. Maroto, S. Lee, Y. Huh, Z. Sun, A. Miguel, S.R. King, R. Cohen, and J. Lee. 2008. Cucurbit grafting. Crit. Rev. Plant Sci. 27:50-74.

Deakin, J.R., G.W. Bohn, and T.W. Whitaker. 1971. Interspecific hybridization in Cucumis. Econ. Bot. 25:195-211.

Dong, K., R.A. Dean, B.A. Fortnum, and S.A. Lewis. 2001. Development of PCR primers to identify species of root-knot nematodes: Meloidogyne arenaria, M. hapla, M. incognita and M. javanica. Nematropica 31:271-280.

Duniway, J.W. 2002. Status of chemical alternatives to methyl bromide for pre-plant fumigation of soil. Phytopathology 92:1337-1343.

Faske, T.R. 2013. Penetration, post-penetration development, and reproduction of Meloidogyne incognita on Cucumis melo var. texanus. J. Nematol. 45:58-65.

Fassuliotis, G. 1967. Species of Cucumis resistant to the root-knot nematode, Meloidogyne incognita acrita. Plant Dis. Rpt. 51:720723 .

Fassuliotis, G. 1970. Resistance of Cucumis spp. to the root-knot nematode, Meloidogyne incognita acrita. J. Nematol. 2:174-178.

Guan, W., X. Zhao, R. Hassell, and J. Thies. 2012. Defense mechanisms involved in disease resistance of grafted vegetables. HortScience $47: 167-170$.

Guan, W., X. Zhao, D.D. Treadwell, M.R. Alligood, D.J. Huber, and N.S. Dufault. 2013. Specialty melon cultivar evaluation under organic and conventional production in Florida. HortTechnology 23:905-912.

Handoo, Z.A., A.P. Nyczepir, D. Esmenjaud, J.G. Van Der Beek, P. Castagnone-Sereno, L.K. Carta, A.M. Skantar, and J.A. Higgins. 2004. Morphological, molecular, and differential-host characterization of Meloidogyne floridensis $\mathrm{n}$. sp. (Nematoda: Meloidogynidae), a root-knot nematode parasitizing peach in Florida. J. Nematol. 36:20-35.

Hanna, H.Y. 2000. Double-cropping muskmelons with nematode-resistant tomatoes increases yield, but mulch color has no effect. HortScience 35:1213-1214.

Huang, Y., R. Tang, Q. Cao, and Z. Bie. 2009. Improving the fruit yield and quality of cucumber by grafting onto the salt tolerant rootstock under $\mathrm{NaCl}$ stress. Sci. Hort. 122:26-31.

Hussey, R.S. and K.R. Barker. 1973. Comparison of methods for collecting inocula of Meloidogyne spp. including a new technique. Plant Dis. Rpt. 57:1025-1028.

Jenkins, W.R. 1964. A rapid centrifugal flotation technique for separating nematodes from soil. Plant Dis. Rpt. 48:692.

Kokalis-Burelle, N. and E.N. Rosskopf. 2011 Microplot evaluation of rootstocks for control of Meloidogyne incognita on grafted tomato, muskmelon, and watermelon. J. Nematol. $43: 166-171$.

Lee, J.M. and M. Oda. 2003. Grafting of herbaceous vegetable and ornamental crops. Hort. Rev. 28:61-124.

Lopez-Galarza, S., A. San Bautista, D.M. Perez, A. Miguel, C. Baixauli, B. Pascual, J.V. Maroto, and J.L. Guardiola. 2004. Effects of grafting and cytokinin-induced fruit setting on colour and sugar-content traits in glasshouse-grown triploid watermelon. J. Hort. Sci. Biotechnol. 79:971-976.
Martin, F.N. 2003. Development of alternative strategies for management of soilborne pathogens currently controlled with methyl bromide. Annu. Rev. Phytopathol. 41:325-350.

Miguel, A., J.V. Maroto, A. San Bautista, C. Baixauli, V. Cebolla, B. Pascual, S. López, and J.L. Guardiola. 2004. The grafting of triploid watermelon is an advantageous alternative to soil fumigation by methyl bromide for control of fusarium wilt. Sci. Hort. 103:9-17.

Nickle, W.R. 1991. Manual of agricultural nematology. Marcel Dekker, Inc., New York, NY.

Nugent, P.E. and P.D. Dukes. 1997. Root-knot nematode resistance in Cucumis species. HortScience 32:880-881.

Oka, Y., N. Shapira, and P. Fine. 2007. Control of root-knot nematodes in organic farming systems by organic amendments and soil solarization. Crop Prot. 26:1556-1565.

Olson, S.M., E.H. Simonne, W.M. Stall, A.J. Gevens, S.E. Webb, T.G. Tayler, S.A. Smith, and J.H. Freeman. 2010. Cucurbit production in Florida, p. 77-106. In: Olson, S.M. and E. Simonne (eds.). Vegetable production handbook for Florida. University of Florida, IFAS Extension, Gainesville, FL.

Rouphael, Y., D. Schwarz, A. Krumbein, and G. Colla. 2010. Impact of grafting on product quality of fruit vegetables. Sci. Hort. 127:172-179.

Sasser, J.N., C.C. Carter, and K.M. Hartman. 1984. Standardization of host suitability studies and reporting of resistance to root-knot nematodes. NC State University Graphics, Raleigh, NC.

Sigüenza, C., M. Schochow, T. Turini, and A. Ploeg. 2005. Use of Cucumis metuliferus as a rootstock for melon to manage Meloidogyne incognita. J. Nematol. 37:276-280.

Strang, J., K. Bale, J. Snyder, D. Carpenter, and C. Smigell. 2007. Specialty melon variety evaluations (Kentucky). Midwest vegetable trial report for 2007. 4 Mar. 2014. <https:// www2.ag.purdue.edu/hla/fruitveg/MidWest $\%$ 20Trial\%20Reports/2\%202_Strang.pdf $>$.

Taylor, A.L. and J.N. Sasser. 1978. Biology, identification and control of root-knot nematodes (Meloidogyne spp.). NC State University Graphics. Raleigh, NC.

Thies, J. and A. Levi. 2013. Response of African horned cucumber (Cucumis metulifer) to southern root-knot nematode, Meloidogyne incognita. Phytopathology 103:S2.144 (abstract).

Thies, J., S. Buckner, and A. Levi. 2013. African horned cucumber rootstocks for managing rootknot nematodes in grafted melon. J. Nematol. 45:320 (abstract).

Thies, J.A., R.F. Davis, J.D. Mueller, R.L. Fery, D.B. Langston, and G. Miller. 2003. Doublecropping cucumbers and squash after resistant bell pepper for root-knot nematode management. Plant Dis. 88:589-593.

Thies, J.A., S.B. Merrill, and E.L. Corley. 2002. Red food coloring stain: New, safer procedures for staining nematodes in roots and egg masses on root surfaces. J. Nematol. 34:179-181.

Thomason, I.J. and H.E. McKinney. 1959. Reaction of some Cucurbitaceae to root-knot nematodes (Meloidogyne spp.). Plant Dis. Rpt. 43:448-450.

Trionfetti Nisini, P., G. Colla, E. Granati, O. Temperini, P. Crinò, and F. Saccardo. 2002. Rootstock resistance to fusarium wilt and effect on fruit yield and quality of two muskmelon cultivars. Sci. Hort. 93:281-288.

Walters, S.A., T.C. Wehner, and K.R. Barker. 1993. Root-knot nematode resistance in 
cucumber and horned cucumber. HortScience. Nematropica 28:151-154.

Walters, S.A., T.C. Wehner, M.E. Daykin, and K.R. Barker. 2006. Penetration rates of root-knot nematodes into Cucumis sativus and $C$. metuliferus roots and subsequent histological changes. Nematropica 36:231242.

Wehner, T.C., S.A. Walters, and K.R. Barker. 1991. Resistance to root-knot nematodes in cucumber and horned cucumber. J. Nematol. 23:611-614.

Williamson, V.M. and P.A. Roberts. 2010. Mechanisms and genetics of resistance, p. 301-325. In: Perry, R.N., M. Moens, and J.L. Starr (eds.). Root-knot nematode. CAB International Wallingford, UK.

Xu, C., T. Li, and H. Qi. 2006. Effects of grafting on development, carbohydrate content, and sucrose metabolizing enzymes activities of muskmelon fruit. Acta Hort. Sinica 33:773778.

Zeck, W.M. 1971. A rating scheme for field evaluation of root-knot nematode infestations. Pflanzenschutz-Nachrichten Bayer 24: 141-144.

Zitter, T.A., D.L. Hopkins, and C.E. Thomas. 1996. Compendium of cucurbit diseases (Disease compendium series). 1st Ed. APS Press, St. Paul, MN 